\title{
Seasonality of bumblebee spillover between strawberry crops and adjacent pinewoods
}

\author{
Alejandro Trillo ${ }^{1}$, Ana Montero-Castaño ${ }^{2}$, Montserrat Vilì ${ }^{1}$ \\ ${ }^{1}$ Estación Biológica de Doñana (EBD-CSIC), Avda. Américo Vespucio 26, Isla de la Cartuja, E-41092, Sevilla, Spain \\ ${ }^{2}$ School of Environmental Sciences, University of Guelph, 607 Gordon St., Guelph, ON N1G 1Y2, Canada
}

Received 3 January 2020 - Revised 25 May 2020 - Accepted 5 June 2020

\begin{abstract}
In agricultural landscapes, differences in floral resources provided by crops compared with adjacent habitats promote the spillover of pollinators seeking to fulfil their feeding needs. These foraging patterns play an important role in both crop production and wild plant fitness. However, in classical observational studies, pollinator spillover patterns may be confounded by differences in pollinator phenologies and population sizes. To avoid these confounding effects, we quantified the combined effect of relative floral availability and season on pollinator spillover between strawberry crops and adjacent pinewoods by using commercial bumblebee colonies. We used 60 colonies that were placed in 6 open polytunnel strawberry crops and in 8 pinewoods adjacent to crops in landscapes with either low or high berry (mostly strawberry) crop cover. We repeated the experiment in winter and in spring to account for differences in flower resource availability. While strawberries were in bloom during the entire study period, wild flowering plants were scarce and abundant in winter and in spring, respectively. Spillover in crops was quantified as the percentage of bumblebee individuals that carried pollen from non-berry flowers, while spillover in pinewoods was quantified as the percentage of individuals that carried pollen from berry flowers. Overall, 526 bumblebees were collected. We found them carrying the pollen of 15 plant taxa in winter and 39 in spring, in accordance with seasonal floral availability. In crop colonies, around $30 \%$ of bumblebees spilled over into non-berry habitats in winter and 78\% in spring, regardless of crop cover in the surrounding landscape. However, in pinewood colonies, we found an interaction effect between season and crop cover: even though on average $34 \%$ of bumblebees spilled over into berry crops, in winter it was almost twice in landscapes with high crop cover. Spillover patterns mainly mirrored seasonal changes in floral availability between habitats.
\end{abstract}

\section{agricultural landscapes / Bombus terrestris / central place foragers / foraging dynamics / pollen loads}

\section{INTRODUCTION}

Differences in the availability of resources among habitat types promote cross-habitat spillover of functionally relevant mobile organisms seeking to fulfil their resource needs (Dunning et al., 1992). Spillover not only contributes to the maintenance of the organisms involved and

Electronic supplementary material The online version of this article (https://doi.org/10.1007/s13592-020-00782-1) contains supplementary material, which is available to authorized users.

Corresponding author: A. Trillo, atrillo@ebd.csic.es Manuscript editor: Cedric Alaux their populations but also plays an important role in multiple ecological processes, such as seed dispersal and pollination (Rand et al., 2006; Tscharntke et al., 2012).

The spillover of organisms is very common and important in agricultural landscapes. Crop habitats represent about one-third of global icefree land area (Ellis et al., 2010). In these habitats, pollinators are among the most influential organisms through their contribution to crop fruit and seed set. Globally, they provide pollination services to $\sim 75 \%$ of the major crop species (Klein et al., 2007). In fact, over the past few decades, the area devoted to crops that are attractive to and 
benefit from pollinators has disproportionately increased compared with non-pollinator dependent crops (Aizen et al., 2008). Moreover, pollinators contribute to the reproduction of $87.5 \%$ of angiosperm species, which are also essential for wild plant communities (Ollerton et al., 2011).

Among pollinators, insects, and bees in particular, are the primary pollinators of most entomophilous plants (Winfree, 2010). Unlike other taxa such as flies or butterflies, bees are central place foragers, i.e. they have fixed nest sites that constrain distances to foraging locations (Beutler and Loman, 1951; Stephens and Krebs, 1986). Therefore, the spatial distribution and temporal availability of floral resources within their flying ranges play important roles in their foraging dynamics (Dukas and Edelstein-Keshet, 1998; Steffan-Dewenter and Kuhn, 2003).

Crops usually provide monospecific, but highly abundant and spatially homogenous, floral resources, that are usually available for short periods of time. In contrast, natural habitats provide diverse, though often scattered, plant species that in many cases flower successively for long periods. These habitat differences in floral resources help explain why commercially managed bees, which are the generalist pollinators frequently used for pollination services (Potts et al., 2016), and wild bees spill over between crops and natural habitats to optimise their food intake (González-Varo and Vilà, 2017; Montero-Castaño et al., 2016; Whittington et al., 2004).

To date, most studies on bee spillover between crops and natural habitats have compared bee abundance in each habitat in periods when crops flowered massively and when flowering ceased (reviewed by Blitzer et al., 2012). In these studies, bees tended to spill over from natural habitats to crops when the latter flowered and the reverse when crop flowering ceased. However, the spillover variation generally attributed to changes in flower availability, may hide phenological patterns of bee populations and communities (Kennedy et al., 2013). In addition, some recent studies have revealed the role that the surrounding landscape plays in modulating bee spillover between habitats (e.g. Danner et al., 2017; González-Varo and Vilà, 2017; González et al., 2016).
In this study, we used commercial bumblebee colonies at similar phenological stages to investigate how seasonal changes in floral availability influence bee spillover between berry crops and non-berry habitats in landscapes with contrasting crop cover. The spillover was measured by identifying the pollen loads carried by bumblebees collected when returning to their colonies. The colonies were placed in monospecific crops (strawberries) and in high floral diversity understory pinewoods near low or high berry crop covers. We repeated the experiment in winter and in spring. In berry crops, floral availability is spatially homogenous and abundant in both winter and spring, while in pinewood understories, floral availability is patchily distributed and scarce in winter and thrives in spring. We specifically aimed (i) to quantify the bidirectional bumblebee spillover between berry crops and non-berry habitats and (ii) to investigate the influence of crop cover in the landscape and season in this spillover.

We expect bumblebees from colonies placed in both habitats to visit plants inside and outside of crops because they are generalist pollinators. We expect the magnitude of the spillover to be mediated by crop cover in the landscape and by season. Thus, in winter, we expect most bumblebees to visit crops due to the high abundance of strawberry flowers, while in spring, we expect most of them to visit wild plants due to the high floral diversity in this season in non-berry habitats, regardless of whether colonies are placed inside or outside crops. In addition, we expect bumblebee spillover from pinewood colonies to berry crops to increase with crop cover, especially in winter when there is less availability of wild floral resources than in spring.

\section{MATERIALS AND METHODS}

\subsection{Study system}

The study was conducted in a $30 \mathrm{~km} \times 20 \mathrm{~km}$ area in the Guadalquivir Valley, Province of Huelva (SW Spain, Figure 1 and Table S1), in January and April 2015. The climate is typically Mediterranean with very mild winters. In January, the coldest month, the mean of the maximum temperatures is $16.2{ }^{\circ} \mathrm{C}$ (AEMET, 2015), allowing bumblebee foraging activity (Trillo et al., 2019a). 

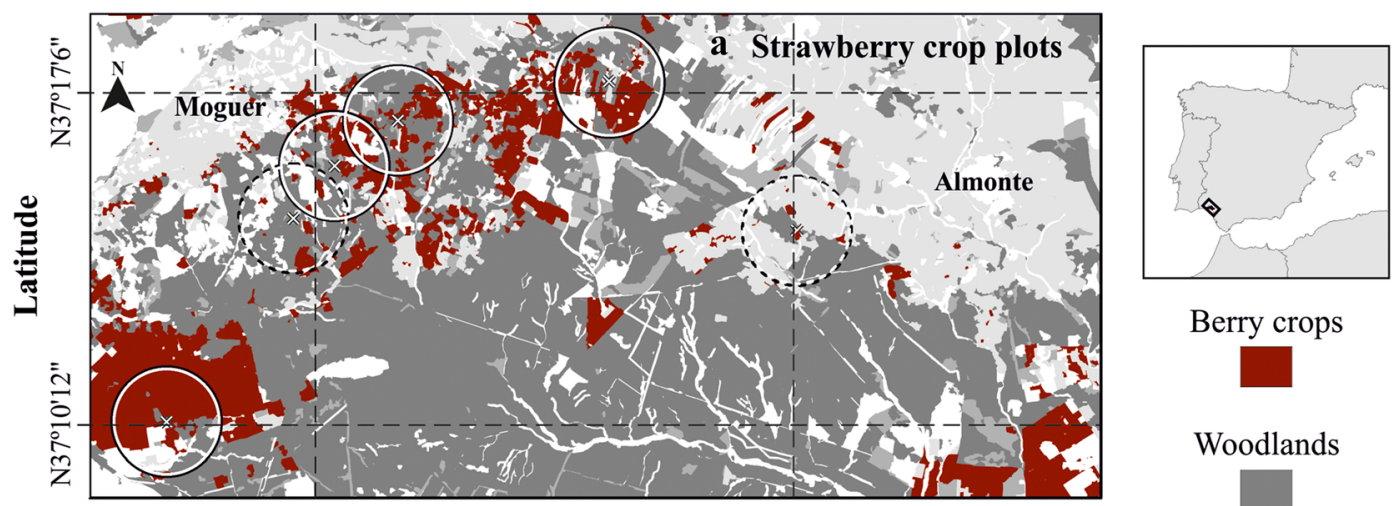

Berry crops

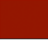

Woodlands
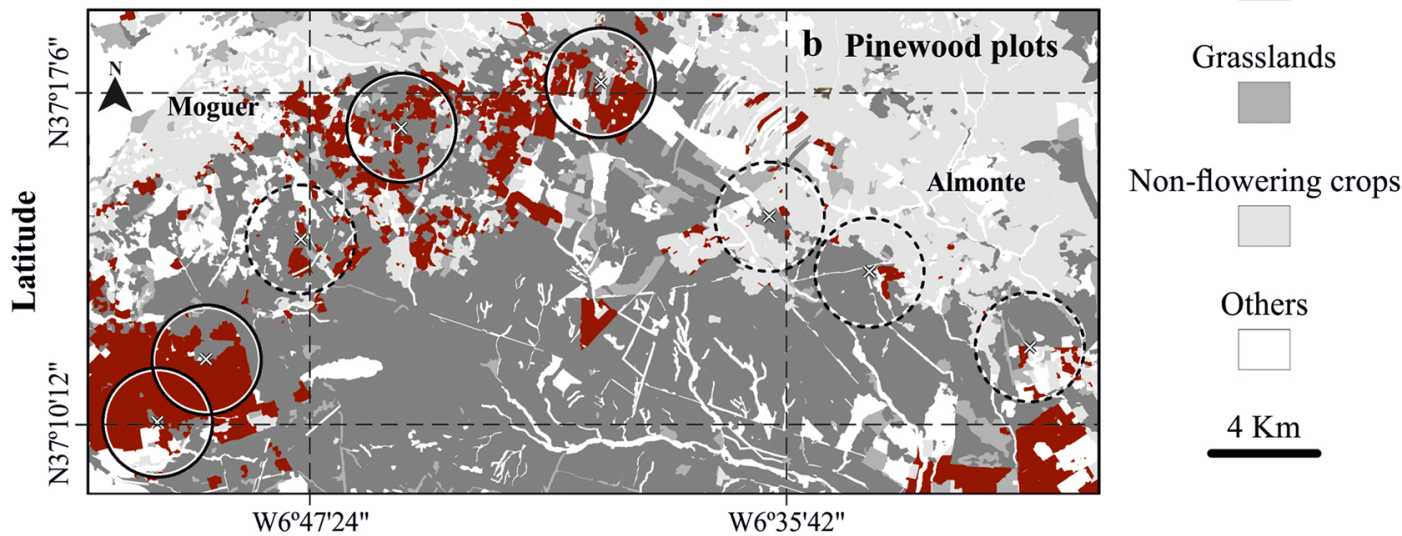

Longitude

Figure 1. Geographical distribution of strawberry crop plots (A) and pinewood plots (B) located in the Province of Huelva (SW Spain). Circles with solid lines indicate landscapes with high crop cover, while circles with dashed lines indicate landscapes with low crop cover, in both crop plots (A) and pinewood plots (B). Names denote towns.

The main crops in this region are berry fields in open (at the ends and sides) polytunnels. Specifically, strawberry (Fragaria $\times$ ananassa) is the main crop species ( $\sim 70 \%$ of the cultivated area), but there are also raspberries (Rubus idaeus), blueberries (Vaccinium corymbosum) and blackberries (Rubus spp.) (Freshuelva, 2015). The cultivation period extends from November to May, during which time strawberries continuously flower, although there are a greater number of flowers in spring than in winter (e.g. in one of the most cultivated varieties, flower density can vary from 9 flowers $/ \mathrm{m}^{2}$ in winter to 18 flowers $/ \mathrm{m}^{2}$ in spring; see Trillo et al., 2018). The bloom of the other berry crop species is variety dependent, although it only lasts a few weeks. To supply the pollination of berry crops, honeybee (Apis mellifera) hives and bumblebee (Bombus terrestris) colonies are frequently used. In our study, we used bumblebees instead of honeybees as a model system because (i) commercial bumblebee colonies are easily manageable and (ii) their annual life cycle allows meaningful comparisons among colonies at similar phenological stages.

Natural habitats in the region consist of fragmented woodlands of stone pines (Pinus pinea) with a rich understorey of insect-pollinated plants. While in winter a few plant species such as Rosmarinus officinalis and Ulex australis flower (e.g. flower densities can reach 10 flowers $/ \mathrm{m}^{2}$ in some patches; see Trillo et al., 2019b), most entomophilous plants such as Lavandula stoechas, Cistus ladanifer, Echium vulgare, Cytisus gradiflorus and Acacia spp. flower in spring (flower densities can reach 31 flowers $/ \mathrm{m}^{2}$ in some patches; see Trillo et al., 2019a). 


\subsection{Experimental design}

To explore the bidirectional spillover between berry crops and non-berry habitats, we selected 14 plots. The centre of six of the study plots was located in strawberry crops adjacent $(\sim 50 \mathrm{~m})$ to pinewoods, while the centre of eight of the study plots was located in pinewoods adjacent $(\sim 50 \mathrm{~m})$ to strawberry crops (Figure 1). To meet independence criteria between study plots, the average distance between the centres of the study crops was $5.5 \pm 1.4 \mathrm{~km}$ (mean $\pm \mathrm{SE}$, hereafter) ranging from 2.4 to $8.8 \mathrm{~km}$, and the average distance between the centres of the study pinewoods was $4.9 \pm 0.6 \mathrm{~km}$ ranging from 3.1 to $7.5 \mathrm{~km}$. Bumblebee foragers do not usually fly distances greater than $2 \mathrm{~km}$ (Osborne et al., 2008).

To explore whether the spillover between berry crops and non-berry habitats was influenced by crop cover at the landscape scale, six of the study plots were placed in landscapes with low berry crop cover and eight in landscapes with high berry crop cover. Study landscapes included a 2-km-radius buffer area from plot centres. In low-crop landscapes (2 crop and 4 pinewoods), average berry crop cover was 5.6 $\pm 1.5 \%$, ranging from 1.8 to $10.4 \%$, while for highcrop landscapes (4 crop and 4 pinewoods), it was $43.8 \pm 5.7 \%$, ranging from 27.9 to $63.9 \%$. The rest of the land use types were mainly woodlands but also grasslands, non-flowering crops, wetlands, urban areas and denuded soil (Figure 1 and Table S1). Land use covers were calculated using ArcGIS (ESRI, 2011) based on the land use map of Andalucía from 2011 (Moreira et al., 2011).

In the centre of each study plot, we placed two commercially produced Bombus terrestris colonies for 1 month. Colonies were purchased from Koppert Biological Systems. We used two colonies per plot to minimise the risk of colony malfunction or loss. Moreover, we expected individuals from different colonies but in the same landscape to exploit similar floral resources (Munidasa and Toquenaga, 2010; Saifuddin and Jha, 2014). All colonies were at a similar phenological stage and included a queen and 50-100 workers each. They were supplied with a syrup solution ad libitum in a plastic box covered with cardboard. In crops, we hung colonies $(\sim 20 \mathrm{~m}$ from each other) inside different polytunnels, while in pinewoods, we placed them on the ground hidden in wooden boxes to avoid predation.
To explore the seasonality of the spillover of bumblebees between berry crops and non-berry habitats, we repeated the study in January and in April (hereafter referred to as winter and spring, respectively). These months cover the main flowering periods of crops and wild plants and maximise the differences in floral availability between habitat types in the study region.

\subsection{Bumblebee survey and pollen loads}

We analysed body pollen loads to explore the range of different plants that bumblebees visit and to quantify spillover between berry crops and nonberry habitats. We used body pollen instead of pollen from scopas, as body pollen influences the pollination function through its deposit on stigmas (e.g. Bartomeus et al., 2008) and thus its measurement represents spillover of functionally important pollinators.

In each study plot and in each season, we collected bumblebee workers as they returned to their colonies on two different days: one during the second week and another during the third week after the colonies were placed in the field, thus obtaining a broad representation of the visited plants, while controlling for colony phenology.

Bumblebees were captured using aerial nets and then frozen $\left(-20^{\circ} \mathrm{C}\right)$ in individual clean vials for later preparation of pollen samples. Captures were conducted on sunny, warm $\left(\geq 14{ }^{\circ} \mathrm{C}\right)$ and non-windy days. We missed data from two colonies placed in two different crops in landscapes with high crop cover: one in winter and another in spring. This was likely due to colony malfunction (i.e. there were almost no foragers working in those colonies). Consequently, for those plots, the number of bumblebees captured was approximately $35 \%$ lower than the average (see Results).

A cube $(0.3 \mathrm{~cm} \times 0.3 \mathrm{~cm})$ of fuchsin jelly was rubbed on the body of each bumblebee (Beattie, 1971). Each cube was mounted on a slide and all pollen grains within 20 random fields at $\times 200$ magnification were identified visually. For pollen identification, we used a reference pollen collection from the study area as well as the help of experts. However, when identification could not be performed at the species level, pollen grains were assigned to a higher taxonomic level, such as genus 
or family (Table S2). Nevertheless, our main aim in this study was to quantify spillover, i.e. pollen from berry or non-berry flowers, rather than to identify each visited plant species. Berry pollen included Fragaria $\times$ ananassa, Rubus idaeus and Vaccinium corymbosum. The pollen of the crop species was distinguishable from that of wild plant species, as in the study region there are no wild berry species, except for Rubus ulmifolius, which flowers after the study period and is not very abundant in the study region. The presence of more than ten pollen grains of a taxon in the 20 microscope fields per individual was considered proof that the taxon was visited by the bumblebee (for a similar approach, see Bosch et al., 2009).

\subsection{Statistical analyses}

To avoid pseudoreplication, spillover was calculated per plot instead of per colony. Spillover in crops was quantified as the percentage of individuals that carried pollen from non-berry flowers, while spillover in pinewoods as the percentage of individuals that carried pollen from berry flowers.

To analyse differences in bumblebee spillover between habitats, we used generalised linear mixed models (GLMM; Binomial error distribution) for crop and pinewood colonies separately. The response variable 'bumblebee spillover' was coded as a two-column matrix (i.e. number of individuals per plot that spilled over vs. number of individuals that did not spill over). Season (winter/spring) and crop cover in the landscape (low/high) were included in the models as fixed factors, as well as their interaction. Plot was included as a random factor to account for the re-sampled plots in winter and spring. Post hoc comparisons among treatments were conducted by building contrast matrices.

Statistical analyses were computed in $\mathrm{R}$ (v.3.1.3, R Core Team, 2014). For GLMMs, we used the lme4 package (Bates et al., 2014) and for contrast matrices the multcomp package (Hothorn et al., 2013).

\section{RESULTS}

We collected 526 (265 in winter and 261 in spring) bumblebees, with an average of $18.8 \pm 0.6$ individuals per plot (i.e. two colonies pooled) per season. Approximately $81 \%$ and $87 \%$ of bumblebees from crop and pinewood colonies, respectively, transported pollen on their bodies exclusively from a single habitat type (i.e. berry or nonberry). Overall, we found that bumblebees from both crop and pinewood colonies visited 15 and 39 plant taxa in winter and in spring, respectively, including berry crop species (Table S2A and B).

\subsection{Bumblebee spillover from berry crops to non-berry habitats}

Season had a significant effect on the spillover of bumblebees from berry to non-berry crop habitats. In winter, on average, $30.0 \pm 6.6 \%$ of bumblebees spilled over into non-berry habitats, while in spring, $78.1 \pm 5.9 \%$ spilled over. However, neither crop cover nor its interaction with season had an effect on bumblebee spillover (see Figure 2A and Table I).

\subsection{Bumblebee spillover from non-berry habitats to berry crops}

Season and crop cover interacted, influencing the spillover of bumblebees from non-berry to berry crop habitats. Specifically, the percentage of bumblebees spilling over from non-berry to berry crop habitats was on average $34 \%$. However, in winter in landscapes with high crop cover, the spillover reached on average $66.9 \pm 10.6 \%$, which was significantly greater than in spring $(29.6 \pm 14.6 \%)$. Moreover, in winter, bumblebee spillover was (marginally) greater in landscapes with high crop cover $(66.9 \pm 10.6 \%)$ as compared with landscapes with low crop cover $(36.8 \pm$ $12.1 \%$ ) (see Figure 2B and Table I).

\section{DISCUSSION}

We found that commercial bumblebees (Bombus terrestris) from crop and pinewood colonies transported pollen from a wide range of plant taxa across habitats, as observed in other studies (e.g. Foulis and Goulson, 2014; Kämper et al., 2016). The variety of pollen found in the colonies was greater in spring than in winter, reflecting floral availability in the landscape during both of the study seasons. 


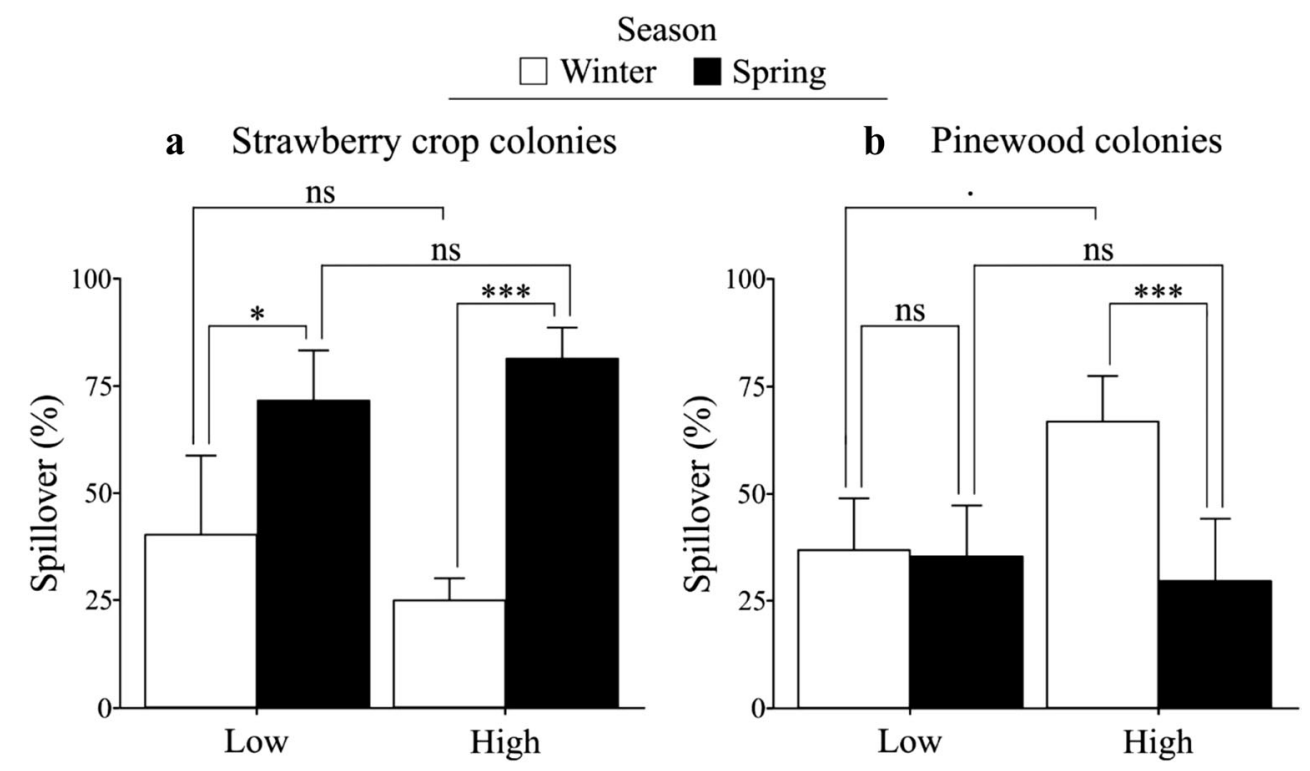

Figure 2. Mean + SE spillover of bumblebees (A) from berry to non-berry crop habitats (strawberry crop colonies) and (B) from non-berry to berry crop habitats (pinewood colonies) in winter (white bars) and spring (black bars) in landscapes with low and high crop cover. Spillover from berry to non-berry crop habitats is the percentage of individuals that carry pollen from non-berry flowers, while spillover from non-berry to berry crop habitats is the percentage of individuals that carry pollen from berry flowers. Significance levels: ${ }^{* * * *} p \leq 0.001,{ }^{* * *} p \leq 0.01,{ }^{*} p \leq$ $0.05,{ }^{\circ} p \leq 0.10,{ }^{\mathrm{ns}} p>0.10$.

This flexible behaviour and the ability to track resources at the landscape scale may enable bumblebees to meet colony nutritional needs and thus presumably thrive in these dynamic and fragmented landscapes (Osborne et al., 2008; Westphal et al., 2003).

Table I. Generalised linear mixed models of the effects of crop cover (low and high) in the landscape (2-km-radius buffer) and season (winter and spring) on bumblebee spillover between berry and non-berry crop habitats. The contrast column indicates the specific interactions tested through the contrast matrices. Significance levels: ${ }^{* * * *} p \leq$ $0.001,{ }^{* *} p \leq 0.01,{ }^{*} p \leq 0.05,{ }^{*} p \leq 0.10$

\begin{tabular}{|c|c|c|c|c|c|c|}
\hline Model & Contrast & Estimate & SE & $Z$ & $p$ value & \\
\hline \multicolumn{7}{|c|}{ From berry to non-berry crop habitats } \\
\hline & Low: winter vs. spring & -1.439 & 0.498 & -2.891 & 0.014 & $*$ \\
\hline & High: winter vs. spring & -2.658 & 0.440 & -6.046 & $<0.001$ & $* * *$ \\
\hline & Winter: low vs. high & 0.763 & 0.559 & 1.365 & 0.466 & \\
\hline & Spring: low vs. high & -0.456 & 0.575 & -0.794 & 0.829 & \\
\hline \multicolumn{7}{|c|}{ From non-berry to berry crop habitats } \\
\hline & Low: winter vs. spring & 0.061 & 0.341 & 0.178 & 0.996 & \\
\hline & High: winter vs. spring & 1.805 & 0.386 & 4.680 & $<0.001$ & $* * *$ \\
\hline & Winter: low vs. high & -1.423 & 0.615 & -2.316 & 0.073 & \\
\hline & Spring: low vs. high & 0.321 & 0.625 & 0.514 & 0.946 & \\
\hline
\end{tabular}




\subsection{Spillover from berry crops to non- berry habitats}

Bumblebees from colonies placed inside berry crops foraged in surrounding non-berry habitats. This finding agrees with studies conducted in other latitudes where, although bumblebee colonies were placed in crops with high quantities of floral resources, many individuals foraged outside of these crops (Bobiwash et al., 2017; Foulis and Goulson, 2014; Murray et al., 2013). In addition, we observed that the magnitude of the spillover (i.e. the percentage of bumblebee workers carrying pollen from non-berry habitats) changed between seasons. That is, while a considerable number of individuals spilled over from polytunnels into non-berry habitats during the entire study period, in spring this number was 2.6 times higher than in winter. This increase in spring is probably a response to higher floral availability outside polytunnels during this season (Whittington et al. 2004). Such an adaptive spillover may allow bumblebees to amplify their diets according to the availability of other floral resources. It has been found that bumblebees need diverse diets to maintain the health and proper development of their colonies (Brunner et al., 2014; Tasei and Aupinel, 2008). Therefore, despite the massive amount of monospecific floral resources that crops can punctually offer to pollinators and the presumably lower traveling costs of foraging inside the crop, part of the colony worker population constantly travels outside of crops.

Conversely, and contrary to what we expected, we found no effect of berry crop cover on bumblebee spillover from crops to non-berry habitats. In this study system, even in landscapes with low crop cover $(\sim 5.6 \%)$, strawberry flowers are relatively abundant as compared with the number of insect visitors (Trillo et al., 2018) and they do not seem to be a limiting resource. Higher crop floral availability does not imply a higher proportion of individuals from colonies foraging in crops, at least when other resources are available (Danner et al., 2014). It is likely that the crop resource demand for bumblebee colonies was met in landscapes with low crop cover. In fact, in landscapes with high crop cover, there are many bumblebees from the colonies foraging outside of polytunnels, probably as a strategy to meet their nutritional needs, as discussed above.

\subsection{Spillover from non-berry habitats to berry crops}

Bumblebees from colonies placed in pinewoods also foraged inside berry crops. Although those crops offer monospecific floral resources, a considerable number of individuals seem to be attracted by their massive bloom. In fact, bumblebees are frequent and valuable crop pollinators worldwide (Goulson, 2010). The percentage of individuals from pinewood colonies foraging in crops was quite similar across landscapes and seasons (around one-third of the workers carried berry pollen). An exception to this was the high proportion of bumblebees $(67 \%)$ that spilled over from non-berry to berry habitats in landscapes with high crop cover in the winter.

On one hand, the fact that in landscapes with high crop cover, the spillover of bumblebees into berry crops in winter was around twice that in spring suggests that bumblebees are more attracted to the resources offered by wild plants than crop flowers. While crop flowers were relatively abundant in both seasons, most bumblebees foraged outside crops when wild flowers were abundant and diverse in spring. Other studies have shown how pollinators benefit from early or late (i.e. when wild flowers are scarce) flowering crops (Riedinger et al., 2014), but also how they forage more intensively in wild flowers when those are abundant and diverse (Danner et al., 2014; Odoux et al., 2012; Requier et al., 2015).

On the other hand, we did not observe this trend in landscapes with low crop cover. Although to a lesser degree than in landscapes with high crop cover, we would expect a higher spillover to crops in winter than in spring, consistent with a preference for wild plants when they are available. However, the spillover of bumblebees in winter was in fact lower than in spring. One potential explanation for this result is that strawberry flowers might not be very attractive to bumblebees, as suggested in other studies (e.g. BlažyteČereškienè et al., 2012; Trillo et al., 2019b). That, combined with a low cover of these crops in the landscape, may lead to a limited use of crops. Any abundant wild floral resource or multispecific patch on a local scale may attract many 
bumblebees (Jha and Kremen, 2013; Kallioniemi et al., 2017) in winter in those landscapes.

\subsection{Conclusions and potential implications}

We found a stronger influence of season compared with berry crop cover on the bidirectional bumblebee spillover between berry crops and non-berry habitats. This indicates that high abundance and diversity of wild flowering plants in surrounding areas of crops play an important role in attracting individuals, either from crop or pinewood colonies. However, when wild floral resources were scarce and crops abundant at a landscape scale, a higher proportion of bumblebees foraged in crops. We would expect such an adaptive foraging pattern to occur across other agronatural landscapes with flowering crops and, in general, in landscapes with habitats with changing relative floral availability. Nevertheless, other factors outside the scope of this study might also influence these patterns, for instance, the distribution of food patches in the landscape (Ims, 1995), how attractive crops are to pollinators (e.g. strawberry vs. raspberry, see Ellis et al., 2017) and resource competition with other flower visitors (e.g. González-Varo and Vilà, 2017).

The spillover of bumblebees among habitats can have multiple implications in these agro-natural landscapes. For example, besides influencing the provision of pollination services to crops (Desjardins and De Oliveira, 2006; Garibaldi et al., 2013; Marqués et al., 2019) and wild plant communities (Diekötter et al., 2010; Holzschuh et al., 2011), it might affect the success of the bumblebee colonies themselves, which would depend on the quality of crop resources and on how other wild floral resources complement their needs (Westphal et al., 2009). The spillover of commercial bumblebees into natural habitats is also not free of environmental risks, such as the spread of parasites (Colla et al., 2006; Meeus et al., 2011; Trillo et al., 2019a), hybridisation (Cejas et al., 2019; Seabra et al., 2019) and resource competition (Matsumura et al., 2004; Morales et al., 2013) with native pollinators. Therefore, a comprehensive understanding of the factors influencing pollinator spillover in agroecosystems is essential to optimise crop pollination, while preserving the diversity and functioning of wild plant-pollinator communities in adjacent habitats.

\section{ACKNOWLEDGEMENTS}

We thank J. Angelidou, C. Apostolidou, D. Ragel and E. Tsiripli for field assistance and pollen preparation, J. Belmonte and D. Navarro for pollen identification assistance and the editor and anonymous reviewers for their comments and editing suggestions. We also thank the farmers who generously let us conduct our experiments in their fields.

\section{AUTHOR CONTRIBUTION}

AT and MV conceived this research and designed experiments; AT and AMC performed the experiments; AT conducted the data analyses and wrote the first draft of the manuscript; AMC and MV edited and contributed to the writing of the manuscript. All authors read and approved the final manuscript.

\section{FUNDING INFORMATION}

This research was financially supported by the Spanish Ministry of Economy and Competitiveness project FLORMAS ('Influence of mass flowering crops on pollinator biodiversity', project no CGL2012-33801), the Biodiversa-FACCE project ECODEAL ('Enhancing biodiversity-based ecosystem services to crops through optimised densities of green infrastructure in agricultural landscapes', http://www.cec.lu.se/ecodeal, project no PCIN-2014-048) and the FBBVA project ABEJORROS ('Ecological implications of commercial bumblebee spillover into natural areas'). AT was supported by a Severo-Ochoa predoctoral fellowship (SVP-2013-067592).

\section{COMPLIANCE WITH ETHICAL STANDARDS}

Conflict of interest The authors declare that they have no conflict of interest.

Caractère saisonnier de l'alternance de bourdons entre les cultures de fraises et les pinèdes adjacentes. 
paysages agricoles / Bombus terrestris / place centrale des butineuses / dynamique du butinage / charges polliniques.

Saisonalität des Wechsels von Hummeln zwischen Erdbeerpflanzungen und angrenzenden Kiefernwäldern.

\section{Landwirtschaftsflächen / Bombus terrestris / Zentralplatzsammlerinnen / Fouragierdynamik / Pollenladungen.}

\section{REFERENCES}

AEMET. (2015). Valores climatológicos normales. Huelva, Ronda Este. http://www.aemet.es/es/ (accessed 01 September 2015).

Aizen, M. A., Garibaldi, L. A., Cunningham, S. A., Klein, A. M. (2008). Long-term global trends in crop yield and production reveal no current pollination shortage but increasing pollinator dependency. Curr. Biol., 18 (20), 1572-1575.

Bartomeus, I., Bosch, J., Vilà, M. (2008). High invasive pollen transfer, yet low deposition on native stigmas in a Carpobrotus -invaded community. Ann. Bot., 102 (3), 417-424.

Bates, D., Maechler, M., Bolker, B., Walker, S. (2014). lme4: Linear mixed-effects models using eigen and S4. $\mathrm{R}$ package version, $\mathbf{1}, 1-23$.

Beattie, A. J. (1971). A technique for the study of insectborne pollen. Pan-Pac. Entomol., 47, 82.

Beutler, R., Loman, D. (1951). Time and distance in the life of the foraging bee. Bee World, 32, 25-27.

Blažytė-Čereškienè, L., Būda, V., Bagdonaitè, E. (2012). Three wild Lithuanian strawberry species and their pollinators. Plant Syst. Evol., 298 (4), 819-826.

Blitzer, E. J., Dormann, C. F., Holzschuh, A., Klein, A. M., Rand, T. A., Tscharntke, T. (2012). Spillover of functionally important organisms between managed and natural habitats. Agric. Ecosyst. Environ., 146 (1), 34- 43 .

Bobiwash, K., Uriel, Y., Elle, E. (2017). Pollen foraging differences among three managed pollinators in the highbush blueberry (Vaccinium corymbosum) agroecosystem. J. Econ. Entomol., 111 (1), 26-32.

Bosch, J., Martín González, A. M., Rodrigo, A., Navarro, D. (2009). Plant-pollinator networks: adding the pollinator's perspective. Ecol. Lett., 12 (5), 409-419.

Brunner, F. S., Schmid-Hempel, P., Barribeau, S. M. (2014). Protein-poor diet reduces host-specific immune gene expression in Bombus terrestris . Proc. R. Soc. B Biol. Sci.. 281 (1786), 20140128.
Cejas, D., López-López, A., Muñoz, I., Ornosa, C., De la Rúa, P. (2019). Unveiling introgression in bumblebee (Bombus terrestris ) populations through mitogenomebased markers. Anim. Genet., 51 (1), 70-77.

Colla, S. R., Otterstatter, M. C., Gegear, R. J., Thomson, J. D. (2006). Plight of the bumble bee: pathogen spillover from commercial to wild populations. Biol. Conserv., 129 (4), 461-467.

Danner, N., Härtel, S., Steffan-Dewenter, I. (2014). Maize pollen foraging by honey bees in relation to crop area and landscape context. Basic Appl. Ecol., 15 (8), 677684.

Danner, N., Keller, A., Härtel, S., Steffan-Dewenter, I. (2017). Honey bee foraging ecology: season but not landscape diversity shapes the amount and diversity of collected pollen. PLoS One, 12, e0183716.

Desjardins, È. C., De Oliveira, D. (2006). Commercial bumble bee Bombus impatiens (Hymenoptera: Apidae) as a pollinator in lowbush blueberry (Ericale: Ericaceae) fields. J. Econ. Entomol., 99 (2), 443-449.

Diekötter, T., Kadoya, T., Peter, F., Wolters, V., Jauker, F. (2010). Oilseed rape crops distort plant-pollinator interactions. J. Appl. Ecol., 47 (1), 209-214.

Dukas, R., Edelstein-Keshet, L. (1998). The spatial distribution of colonial food provisioners. J. Theor. Biol., 190 (2), 121-134.

Dunning, J. B., Danielson, B. J., Pulliam, H. R. (1992). Ecological processes that affect populations in complex landscapes. Oikos, 65 (1), 169-175.

Ellis, C. R., Feltham, H., Park, K., Hanley, N., Goulson, D. (2017). Seasonal complementary in pollinators of softfruit crops. Basic Appl. Ecol., 19, 45-55.

Ellis, E. C., Goldewijk, K. K., Siebert, S., Lightman, D., Ramankutty, N. (2010). Anthropogenic transformation of the biomes, 1700 to 2000. Glob. Ecol. Biogeogr., 19 (5), 589-606.

ESRI (2011). ArcGIS Desktop: Release 10. Environmental Systems Research Institute, Redlands.

Foulis, E. S. J., Goulson, D. (2014). Commercial bumble bees on soft fruit farms collect pollen mainly from wildflowers rather than the target crops. J. Apic. Res., 53 (3), 404-407.

Freshuelva. (2015). http://www. freshuelva.es/ (accessed 13 November 2015).

Garibaldi, L. A., Steffan-Dewenter, I., Winfree, R., Aizen, M. A., Bommarco, R., et al. (2013). Wild pollinators enhance fruit set of crops regardless of honey bee abundance. Science, 339 (6127), 1608-1611.

González-Varo, J. P., Vilà, M. (2017). Spillover of managed honeybees from mass-flowering crops into natural habitats. Biol. Conserv., 212, 376-382.

González, E., Salvo, A., Defagó, M. T., Valladares, G. (2016). A moveable feast: insects moving at the forest-crop interface are affected by crop phenology and the amount of forest in the landscape. PLoS One, 11 (7), e0158836

Goulson, D. (2010). Bumblebees: behaviour, ecology and conservation. Oxford University, Oxford. 
Holzschuh, A., Dormann, C. F., Tscharntke, T., SteffanDewenter, I. (2011). Expansion of mass-flowering crops leads to transient pollinator dilution and reduced wild plant pollination. Proc. R. Soc. B Biol. Sci., 278 (1723), 3444-3451.

Hothorn, T., Bretz, F., Westfall, P., Hothom, M. (2013). Package 'multcomp'. Simultaneous inference in general parametric models. R package version, 1.2-13.

Ims, R. A. (1995). Movement patterns related to spatial structures. In Mosaic landscapes and ecological processes (pp. 85-109). Springer, Dordrecht.

Jha, S., Kremen, C. (2013). Resource diversity and landscape-level homogeneity drive native bee foraging. Proc. Natl. Acad. Sci. USA. 110 (2), 555-558.

Kallioniemi, E., Åström, J., Rusch, G. M., Dahle, S., Åström, S., Gjershaug, J. O. (2017). Local resources, linear elements and mass-flowering crops determine bumblebee occurrences in moderately intensified farmlands. Agric. Ecosyst. Environ. 239, 90-100.

Kämper, W., Werner, P. K., Hilpert, A., Westphal, C., Blüthgen, N., Eltz, T., Leonhardt, S. D. (2016). How landscape, pollen intake and pollen quality affect colony growth in Bombus terrestris . Landsc. Ecol., 31 (10), 2245-2258.

Kennedy, C. M., Lonsdorf, E., Neel, M. C., Williams, N. M., Ricketts, T. H., et al. (2013). A global quantitative synthesis of local and landscape effects on wild bee pollinators in agroecosystems. Ecol. Lett., 16 (5), 584 599.

Klein, A. M., Vaissière, B. E., Cane, J. H., SteffanDewenter, I., Cunningham, S. A., Kremen, C., Tscharntke, T. (2007). Importance of pollinators in changing landscapes for world crops. Proc. R. Soc. B Biol. Sci., 274 (1608), 303-313.

Marqués, A., Juan, A., Ruíz, M., Traveset, A., Leza, M. (2019). Improvement of almond production using Bombus terrestris (Hymenoptera: Apidae) in Mediterranean conditions. J. Appl. Entomol., 143 (10), 11321142.

Matsumura, C., Yokoyama, J., Washitani, I. (2004). Invasion status and potential ecological impacts of an invasive alien bumblebee, Bombus terrestris L. (Hymenoptera: Apidae) naturalized in Southern Hokkaido, Japan. Glob. Environ. Res., 8 (1), 51-66.

Meeus, I., Brown, M. J. F., De Graaf, D. C., Smagghe, G. (2011). Effects of invasive parasites on bumble bee declines. Conserv. Biol., 25 (4), 662-671.

Montero-Castaño, A., Ortiz-Sánchez, F. J., Vilà, M. (2016). Mass flowering crops in a patchy agricultural landscape can reduce bee abundance in adjacent shrublands. Agric. Ecosyst. Environ., 223, 22-30.

Morales, C. L., Arbetman, M. P., Cameron, S. A., Aizen, M. A. (2013). Rapid ecological replacement of a native bumble bee by invasive species. Front. Ecol. Environ., 11 (10), 529-534.

Moreira, J. M., Gámez-Ramírez, M., Caturla-Montero, C., Frieyro de Lara, J. E., Solis-Pérez, J. L., Santana-Gutiérrez, J. M. (2011). Mapa de usos y coberturas vegetales del suelo de Andalucía. Sevilla: Junta de Andalucía.

Munidasa, D. T., Toquenaga, Y. (2010). Do pollen diets vary among adjacent bumble bee colonies? Ecol. Res., 25 (3), 639-646.

Murray, T. E., Coffey, M. F., Kehoe, E., Horgan, F. G. (2013). Pathogen prevalence in commercially reared bumble bees and evidence of spillover in conspecific populations. Biol. Conserv., 159, 269-276.

Odoux, J. F., Feuillet, D., Aupinel, P., Loublier, Y., Tasei, J. N., Mateescu, C. (2012). Territorial biodiversity and consequences on physico-chemical characteristics of pollen collected by honey bee colonies. Apidologie, 43 (5), 561-575.

Ollerton, J., Winfree, R., Tarrant, S. (2011). How many flowering plants are pollinated by animals? Oikos, 120 (3), 321-326.

Osborne, J. L., Martin, A. P., Carreck, N. L., Swain, J. L., Knight, M. E., Goulson, D., Hale, R. J., Sanderson, R. A. (2008). Bumblebee flight distances in relation to the forage landscape. J. Anim. Ecol., 77 (2), 406-415.

Potts, S. G., Imperatriz-Fonseca, V., Ngo, H. T., Aizen, M. A., Biesmeijer, J. C., et al. (2016). Safeguarding pollinators and their values to human well-being. Nature, 540 (7632), 220-229.

R Core Team. (2014). R: a language and environment for statistical computing.

Rand, T. A., Tylianakis, J. M., Tscharntke, T. (2006). Spillover edge effects: the dispersal of agriculturally subsidized insect natural enemies into adjacent natural habitats. Ecol. Lett., 9 (5), 603-614.

Requier, F., Odoux, J. F., Tamic, T., Moreau, N., Henry, M., Decourtye, A., Bretagnolle, V. (2015). Honey bee diet in intensive farmland habitats reveals an unexpectedly high flower richness and a major role of weeds. Ecol. Appl., 25 (4), 881-890.

Riedinger, V., Renner, M., Rundlöf, M., Steffan-Dewenter, I., Holzschuh, A. (2014). Early mass-flowering crops mitigate pollinator dilution in late-flowering crops. Landsc. Ecol., 29 (3), 425-435.

Saifuddin, M., Jha, S. (2014). Colony-level variation in pollen collection and foraging preferences among wild-caught bumble bees (Hymenoptera: Apidae). Environ. Entomol., 43 (2), 393-401.

Seabra, S. G., Silva, S. E., Nunes, V. L., Sousa, V. C., Martins, J., et al. (2019). Genomic signatures of introgression between commercial and native bumblebees, Bombus terrestris, in western Iberian Peninsula-Implications for conservation and trade regulation. Evol. Appl., 12 (4), 679-691.

Steffan-Dewenter, I., Kuhn, A. (2003). Honeybee foraging in differentially structured landscapes. Proc. R. Soc. B Biol. Sci., 270 (1515), 569-575.

Stephens, D. W., Krebs, J. R. (1986). Foraging theory. Princeton: Princeton University Press.

Tasei, J. N., Aupinel, P. (2008). Nutritive value of 15 single pollens and pollen mixes tested on larvae produced by 
bumblebee workers (Bombus terrestris, Hymenoptera: Apidae). Apidologie 39, 397-409.

Trillo, A., Brown, M. J. F., Vilà, M. (2019a). Prevalence of Nosema microsporidians in commercial bumblebees (Bombus terrestris) is not related to the intensity of their use at the landscape scale. Apidologie, 50 (2), 234-242.

Trillo, A., Herrera, J. M., Vilà, M. (2018). Managed bumble bees increase flower visitation but not fruit weight in polytunnel strawberry crops. Basic Appl. Ecol., 30, 32-40.

Trillo, A., Montero-Castaño, A., González-Varo, J. P., González-Moreno, P., Ortiz-Sánchez, F. J., Vilà, M. (2019b). Contrasting occurrence patterns of managed and native bumblebees in natural habitats across a greenhouse landscape gradient. Agric. Ecosyst. Environ., 272, 230-236.

Tscharntke, T., Tylianakis, J. M., Rand, T. A., Didham, R. K., Fahrig, L., et al. (2012). Landscape moderation of biodiversity patterns and processes-eight hypotheses. Biol. Rev., 87 (3), 661-685.
Westphal, C., Steffan-Dewenter, I., Tscharntke, T. (2003). Mass flowering crops enhance pollinator densities at a landscape scale. Ecol. Lett., 6 (11), 961-965.

Westphal, C., Steffan-Dewenter, I., Tscharntke, T. (2009). Mass flowering oilseed rape improves early colony growth but not sexual reproduction of bumblebees. J. Appl. Ecol. 46 (1), 187-193.

Whittington, R., Winston, M. L., Tucker, C., Parachnowitsch, A. L. (2004). Plant-species identity of pollen collected by bumblebees placed in greenhouses for tomato pollination. Can. J. Plant Sci., 84 (2), 599-602.

Winfree, R. (2010). The conservation and restoration of wild bees. Ann. N. Y. Acad. Sci., 1195 (1), 169-197.

Publisher's note Springer Nature remains neutral with regard to jurisdictional claims in published maps and institutional affiliations. 